\title{
Ethics Erosion in Capital Market: Lehman Brothers' Case Study of Repo 105
}

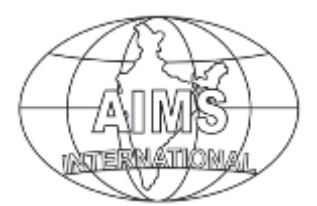

ISBN: 978-1-943295-16-6

\author{
Sumit Kumar \\ Pankaj Kumar Baag \\ Indian Institute of Management \\ (sumit01phdpt@iimk.ac.in) \\ (baagpankaj@iimk.ac.in)
}

\begin{abstract}
This paper synthesizes the details of the whole accounting misdeed using Repo-105 as an instrument in the Lehman Brothers' case. Roles and responsibilities of internal staffs and vendors have been discussed to access on a high level responsibility and the ownership assessment of this financial fiasco. The paper discusses in detail the notion of Business ethics in the context of financial intermediary using the concept of "Deontological Ethics" as a premise with a relevance to capital market and cost of reputation. The paper suggests improving the management culture and the independence of external bodies in these firms.
\end{abstract}

Keywords: REPO 105 Accounting, Business Ethics, Capital Market, Instrument Fraud, Financial Intermediary

\subsection{The Context}

\section{Introduction}

Investment firms have policies and practices that define their competence and professionalism. Among the regulations that govern their day-to-day operations are the considerations of ethics. Ethics are philosophical norms that promote good behaviour in an organization. The most primary goal of ethics is to enhance integrity and loyalty between the investors and the investment companies. Failing to observe the ethical guidelines may cost firms their investors through a damaged reputation. The Lehman Brothers investment company is an example of a firm that suffered liquidation owing to its consistency in ethical malpractices. The main contributor to the failure of the company was the investment on mortgage leverages, which fell tremendously towards the closure of the year 2007 (Beduneau and Gizard, 2016). It also engaged in unethical accounting, where the repo 105 accounting transactions were used to cover the liabilities in the balance sheets.

The practice painted a false image of their standing in the stock market; thus, giving a piece of misleading information to the investors. The regression in their stock prices hit the peak when banks were ordered to reduce their leverages in a bid to control the financial crisis of the year 2008 in the US (Beduneau \& Gizard, 2016). The mortgage housing business also registered a lot of losses during the period. The company deteriorated and filed an insolvency plea on 15 th September 2008 (Beduneau \& Gizard, 2016). The unethical practices were critical to the problems they faced. Future studies should lay focus on the legality of repo 105 transactions and the poor management practices that largely contributed to unethical investment banking for the Lehman Brothers Company.

Policies and practices are significant elements that enhance success in business operations. While regulatory matters are often forcefully implemented, ethics require more personal discipline. Failing to adhere to ethics is detrimental to the business market and the entire venture. It is imperative to adhere to the ethical considerations for customer loyalty and effective operations. Ethics, as reviewed by Aristotle, appeared as a just system of conducting business operations to enhance a mutual gain. The customer and the product/service providers engaged in an interdependent relationship. The protest groups in the United States during the early 1970s led to the formulation of ethics as a philosophical branch of study (Booth, 2010). Legislative processes have since followed to cement the concept of ethics as a law that should be observed by business entities.

\subsection{The Business Ethics}

Business ethics are accepted practices and policies that help in enhancing effective corporate social relations and decisive governance by preventing malpractices such as bribing, false advertising, overpricing, hoarding and other discriminatory activities. Firms should strengthen the practice of ethics according to the regulatory statutes of the countries where they operate (De Roeckand Farooq, 2018). It is considered a fundamental additive in the organizational decision-making process. The ethical decision-making process involves the consideration of intrinsic and extrinsic organizational factors concerning morality. It essential because it ensures harmonious cooperation between the different branches of the business organization.

\subsection{Ethics in the Context of Banking and Financial Institutions}

Ethics is paramount in the financial and banking investment institutions. The principal value expected from such entities is the culture of trust among the key stakeholders. Professionalism entails that high-level integrity be fostered to establish customer trust. The Code of Ethics and Standards of Professional Conduct institution regulates malpractices that conflict with the ethical interests in fiscal institutions. The central concept of ethics in the banking and the financial sector is placing the interests of the investors, and the integrity of the profession ahead of every other personal interest. If such is maintained, competence and respect become paramount, shooting high the chances of success. Failing to uphold ethics may lead to grave consequences among financial investors. A good example is in the case of Daniel Bayly, who was a former head of the 
investment team, at a commercial firm called Merrill Lynch (Beduneau and Gizard, 2016). He was sentenced to 30 months of prison life because of misinterpreting a client's earning for personal gains. The main concepts of ethics in the banking and financial institutions are, therefore, professionalism, the duty to clients and employers, integrity in the capital markets, investment analysis and managing the conflicts of interest. The considerations are further divided into different categories that explain an in-depth analysis of all the legal expectations.

\subsection{Capital Markets and Ethics Consideration}

They are financial institutions that regulate the demand and supply of capital. They establish a mutual relationship between suppliers who have adequate money and those who need money. The capital markets should bear a high level of discipline as far as ethics are concerned. This is mainly because the investment in the form of capital is entitled to a definite return as spelled out in the terms and conditions of engagement. Failure to honour the terms of cooperation is unethical and can lead to legal challenges against the respective financial firms. The primary ethical concepts that control the capital markets are the public misinformation and market manipulation malpractices (Beduneau and Gizard, 2016). All information regarding an investment opportunity must be laid out to the public before the invitation to purchase equities in the company. Hiding relevant information for personal gains is considered unethical because it affects the market credibility. Others also engage in various malpractices that affect the overall market conditions. Malpractices are costly to business enterprises and may lead to adverse consequences. It is essential to uphold high-level ethical standards to ensure that trust is a custom between the investors and the investment institutions.

\subsection{History of Capital Markets and Failure to Consider Ethics}

The Dutch first used capital markets in Holland around the 1700s (Mieszala, 2019). They used the funding from the market to finance various public companies that needed capital to carry on with their normal operations. They were also the first people to develop a fully integrated capital market and the stock market. Later, other countries such as Nepal and later New York developed capital market institutions where the suppliers of funds investment in corporate financial enterprises with the hope of obtaining returns (Mieszala, 2019). There have been several cases where the capital markets have failed to duly comply with the regulations of ethics leading to a collapse in the markets. A good example is the Bank of Credit and Commerce International, which was associated with capital fraud (Booth, 2010). Most of the investors who purchased equities during the initial public offer did not gain their returns as was expected. Another example of a case where ethics was adversely compromised is in the bankruptcy cases of Worldcom and Enron firms (Booth, 2010). They were associated with a culture of creative financing, which was later identified as a manipulative process with the main aim of securing illegal investments from the public. The high-profile cases have caused upheavals in the financial markets, thwarting the interests of other investors.

\subsection{The Consequences}

The repercussions of not adhering to the requirements of ethics may be so grave to financial institutions. It is, therefore, essential to observe the proper standards of ethics. Reputational risks and loss of trust from the clients is a significant concern for most investment groups (Care, 2018). The first main impact on the organization is the loss of credibility to investors and clients. Failing to adhere to the requirements of ethics is grave to the company when entrusted with financial capital, and they fail to return investments as documented in the terms and conditions of the agreement. This leads to a reduction in the stock market ratings and the number of shareholders. The reputation of the firms is also often risked by their inability to comply with ethical considerations. It leads to a significant reduction in productivity and demand. In the long run, the amount of revenue realized significantly drops, and the company loses big in the stock market. Financial losses are also negative consequences of engaging in ethical malpractices. A good example is in the case of Martha Stewart, who was accused of making false assertions to various federal institutions for financial gain (Booth, 2010). She was sentenced to five months in prison and fined 30,000USD (Booth, 2010). Failing to uphold ethical customs may, therefore, lead to financial losses for companies. The Enron and World com companies were also fined for malpractices. The court proceedings associated with the cases are usually expensive. The offenders may be accustomed to forced bails, which may pose adverse financial consequences to the company. They also create inconveniences and waste more time. However, the reputational risk isthe most dangerous consequence of engaging in any ethical malpractice. It makes customers lose trust and confidence; thus, in the long run, they shy away from investing with the organizations.

\subsection{Introduction as a Banking Institution}

\section{Lehman Brothers}

A German founded the Lehman Brothers Organization by the name Henry Lehman. This took place around the year 1844 in Montgomery, Alabama, where he lived. He incorporated his two brothers, Mayer and Emmanuel, into the venture to become co-partners (Mieszala, 2019). They sprang up as a humble venture which dealt in the sale of dry goods. Later, it transformed into cotton trade before the death of Henry Lehman, the founding director. The two brothers continued with the services by expanding the firm to deal with both commodities and brokerage services. There were many financially challenging times for various institutions in the world. However, Lehman Corporation was able to survive the majority of these crises. They endured the two world wars, the great economic depression of the 1930s, and the enormous scandalous initial public offer in the US that took place in 1994 (Mieszala, 2019). However, the housing market of the United States collapsed in the year 
2008, and Lehman Brothers were the most significant casualty of the financial crisis that occurred in the mighty country of the United States then.

\subsection{The Investment Strategies of Lehman Brothers}

The Lehman Brothers Corporation was the fourth most significant fiscal institution in the USA before its collapse. It invested heavily in several Fixed Income Strategies, which were essential in inspiring its growth. Among the most critical styles include fixed income Credit, mortgage services, and corporate credits. Mortgages were the most preferred method of investment for the company. The firm valued subprime mortgage services, which was the ultimate cause of the great commotion leading to its destabilization in 2008 (Fitzpatrick \& Thomson, 2016). The company also earned a fixed income from various trade commodities that it produced. It also had a large source of financial funding through grants and typical donations. It is a firm that had made significant progress before the great collapse that affected its operations in the year 2008.

Some of the investment vehicle/ Investment strategies are as follows

ABS: ABS stands for Asset Backed Securities. These are securities created by collecting, pooling and securitizing Mortgage loans and various other loans. Depending upon the kind of loan pool, it can be Asset Backed Securities, Mortgage-Backed Securities, Securities created out of Student loans, Car and Auto loans etc. It is a leveraged product and the leverage can be very high if the underlying pool of collateral is very risky and with high default probability.

CDS: CDS stands for Credit Default Swap. It is a kind of insurance against default of an underlying bond. Seller of the protection guarantees the protection of par value of the bond and in return protection buyer pays a regular premium to the seller of the protection. On a credit event (Default), buyer of the protection pays accrual till default to the seller of the protection while seller of the protection pays Notional (1-Recovery) to the buyer of the protection where Recovery is the amount recovered as a percentage of par when a defaulted bond is auctioned in the market.

CDS Index: CDS Index is a basket of single name CDS, it's a mechanism to get default exposure to a basket of single name at one go instead of buying several CDS one by one. Unlike CDS when a default happens in the CDS Index, the defaulted names exits from the index and index moves from version 1 to version 2 and to subsequent versions as it sees more defaults but CDS Index trade stays and doesn't get terminated until the entire basket defaults.

CDO Tranches: CDO tranches are very similar to ABS but the only difference it has is that instead of Loan here we securitize CDS Premiums. An SPV is formed which collects, pool and securitize the CDS premiums and create synthetic tranches out of it. This product can be created with a very high leverage and it can provide very high return but inherent risk is also very high. Figure 1 below is a high-level pictorial representation of CDO tranche structure.

Other Credit products included Basket Default Swap, CDO squared, Credit Linked Notes and other complex structured Credit Products

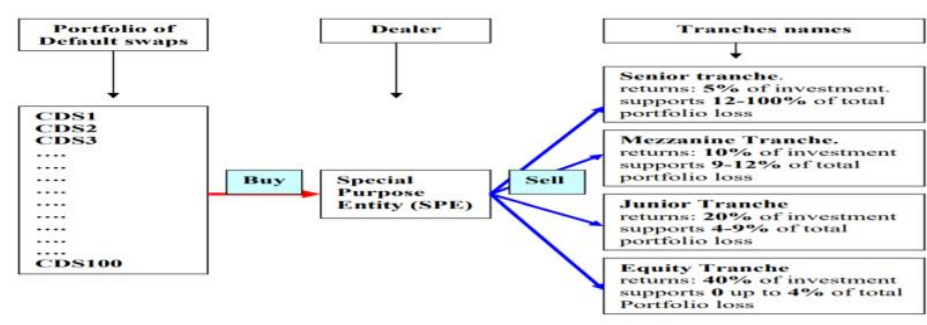

Figure 1 CDO Tranche Structure, Source: Own

\subsection{Bankruptcy of Lehman Brothers: Causes and Impact}

Before the great economic depression of the year 2008, Lehman brothers' profits arose tremendously soon after investing primarily in the real estate mortgage leveraging services. The leading cause of the fall of the company was the fact that it went away from its original objectives and engaged in an uncertain investment, which was booming in the early 2000 s. The firm engaged in the mortgage leveraging services by acquiring five leading firms, which it trusted by lending so much without caution. Among the mortgage firms acquired by the Lehman brothers' corporation were the BNC mortgage services and the Aurora loan services, which majorly offered sub-prime loans (Mieszala, 2019). Although the objective was to obtain capital gains, the scrutiny of all the relevant factors was not done effectively. It was risky to lay faith in new investments that had not proven consistency in the capital market. The results began with tremendous success in a way that no one expected any soon unfortunate occurrence.

Between 2004 and 2006, Lehman Brothers were able to gain an extra 56\% of revenue from the business (Mieszala, 2019). In 2007, it again secured revenues worth 19.3 billion USD (Mieszala, 2019). There was consistency in its profit-making between the years 2004 to 2007 (Mieszala, 2019). No one, therefore, expected the unfortunate circumstance that would befall them in 2008. A drastic turn in the profit generation occurred when the US housing market suddenly crashed. Most of those who were leveraged through the mortgage services failed to honour their pays. The stock market also reduced fast, leading to 
much losses than had never been witnessed. In the long run, Lehman Brothers filed a bankruptcy case on the 15th of September 2008, with total assets worth \$619 billion and debts worth \$619 billion (Mieszala, 2019). This surprised many people who did not foresee the fourth-largest investment firm at that time go down because of some unprofessional investment habits.

The bankruptcy altered the stability of the real estate market prices in the region. The stock market prices reduced instantly, leading to poor investments in such fields. Most people also lost their employment opportunities. Over six million people were rendered jobless owing to the collapse of the Lehman Brothers' corporation (Mieszala, 2019). The unemployment rates in the United States rose by 10\% (Mieszala, 2019). Even, major banks in Pakistan also ran out of their capital stock. They had to seek a bailout from the International Monetary Funds. A 700 billion USD bailout cash was awarded to the financial sector of the United States by President George Bush (Mieszala, 2019). It helped to reduce the impacts that were felt concerning the crisis.

\section{Ethics Theory and Framework}

The review of literature focuses on the ethical frameworks applicable in the banking investment and other relevant research on effective banking practice. The ethical frameworks explored through past studies can be categorized into three major domains. These are as follows:

- The first domain reviews ethics as a standard measure or a rule that people should naturally follow. It is also called the natural law of ethics. Most studies have portrayed ethics to be a natural law that governs man.

- The second domain brings out the concept of ethics as bearing inevitable consequences for those who fail to uphold the high value of ethics.

- The last category puts forward the idea of ethical practices as the development of good habits or characters that transform the behaviour in society.

Based on the three domains, three major theoretical frameworks can be used to define the nature of the ethical practices in the business banking environment. They include consequential ethics, deontological ethics and virtue ethics.

\subsection{Deontological Ethics}

Deontological ethics adopts the concept of ethics as a duty that has to be performed naturally. Most studies have pointed out the deontological theoretical framework as the most suitable definition of ethics. This is mainly because ethics, as a discipline, has been categorized as a natural law. The word is derived from a Greek word deo, which means duty (Reynolds and Newell, 2011). Deontological ethics, thus, takes on the concept of ethics as a practice of the moral philosophy without any form of coercion or motivating factor. It elaborates on the ethical rules and the values that we should live (Reynolds \& Newell, 2011). This conceptual framework is governed by conscience. It means that one naturally loathes doing what is wrong and is inclined to doing the right thing. An example is the laws against murder. People naturally feel it is unlawful to kill even without a definite rule of law regarding such. If the driving motive of doing right comes from the subjective perspective as such, the concept is referred to as deontological ethics.

\subsection{Consequential Ethics}

The consequential ethical framework often oppositely views the concept of ethics from the deontological framework (Bruce, 2018). It relies on the consequences of various actions by people in the financial investment setups. The consequential ethics follows the rules and the established regulations in a bid to evade the grave repercussions that are associated with not following the ethics. It is not a practice that springs out naturally, like in the case of deontological ethics. Thomas Horbes, a behavioural scientist, points out that humans tend to typically pursue actions that will lead to achieving their objectives (Reynolds \& Newell, 2011). This implies that as long as the long-term goal is a sure consequence of adherence to the principles of ethics, most people pursue them.

\subsection{Virtue Ethics}

Virtue ethics is a prominent concept of moral philosophy. It can be traced mainly from the works of Plato, an ancient Greek philosopher, and Aquinas (Reynolds \& Newell, 2011). The theoretical framework pointed out the essence of specific traits revealed by humans, which naturally compel others to do good. Examples of cardinal virtues that influence positive behaviour are temperance, courage, justice and prudence. The deontological and consequential theoretical frameworks mainly lay focus on the things people should do and those that they should refrain from. However, virtue ethics emphasizes the characters we develop, which define the types of decisions we make in life. The aspect of virtue can never be separated from ethics because they are intertwined. In the banking industry, traits or attributes like temperance are significant in setting the right prices, which are fair to everyone. They prevent malpractices that affect the financial positions of the clients in investment firms.

\subsection{Code of Ethics}

Many financial institutions often operate with a standard code of ethics that regulates the interests of every stakeholder in the business. Banks need to focus on educating the staff, notwithstanding their bar in professionalism, about the significance of ethics. Although they may be considered as minor details without importance, failure to pursue the ethical guidelines has plunged the ambitions of many investment firms into a deep sea. The primary importance of upholding ethics is in enhancing 
customer satisfaction and loyalty to the company (Bhala et. al., 2016). One of the main reference points on the codes of ethics is Goldman Sachs' standards of ethical behaviours (Reynolds \& Newell, 2011). They are built around Goldman's primary principle in the practice of investment banking and other business activities. Goldman believed that integrity and honesty were core for success and consistency in the field of business. Some partially succeed because honesty and success are practiced partially. If they re-adopted fully in the business practice, consistency accompanies success because the clients are more satisfied. It is a critical aspect of building the loyalty of customers in business. Among the ethical codes as documented by Goldman Sachs include public disclosure, personal conflict of interests, compliance, and reporting, corporate opportunities, equal opportunities and harassment, protection and proper use of firm assets, fair dealing and confidentiality. All of them are vital to achieving greater heights in the business environment.

\subsection{The term Repo 105}

\section{Repo 105 Transactions}

Repo 105 was a type of loophole in accounting for repurchase (repo) transactions which is used to hide true amounts of leverage. In this repurchase agreement, a company could classify a short-term loan as a sale and subsequently use the cash proceeds from the "sale" to reduce its liabilities. In short we can distinguish Repo 105 as follows (Investopedia)

- Repo 105 was used to gain funds via short-term loans that are backed by collateral.

- Under Repo 105, if a company had the ability to repurchase the assets, it was considered a financing transaction and if it did not, it would be a sale.

- Lehman claimed it gave up effective control because it received only $\$ 100$ for each $\$ 105$ in posted collateral, hence the ' 105 '

\subsection{Repo 105 and Lehman Brothers}

The Lehman Brothers' investment firm found themselves in a financial quagmire towards the end of the year 2007. Although the massive investment in the subprime and prime mortgage leverages had yielded substantial gains in the past three years, the company, for the first time, registered a regression in the prices of their equities in the stock market. It reported consecutive losses and consistent drops in the stock market prices (see below Graph 1). The firm's public image began to raise eyebrows, and this would have prompted the investors to shy away. In a bid to rescue the public image, the company resorted to the Repo 105 transactions, which ended up saving up to $\$ 50$ billion of its liabilities between the closing months of 2007 and the first quarter of the year 2008 (Bruce, 2018). The measures applied in this kind of intervention were completely legal but unethical in many ways. The firm began to lose the critical value of sustainability and transparency.

Lehman Stock Price

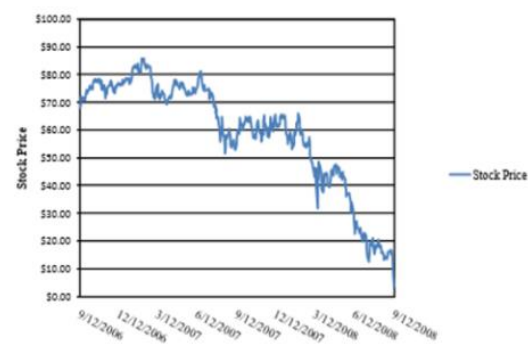

Graph 1 Reduction in the Stock Market Prices, Source: Valukas et. al., 2010

\subsection{Repo 105 Comprehension and Lehman Brothers}

Repo 105 was an accounting transaction that involved securing short-term loans from other companies in terms of collaterals, which would be treated as sales mandatory repurchase options. The transactions helped the Lehman Brothers investment firm to carry out off-balance-sheet transactions, which helped to avoid listing essential securities in their balance sheet reports. The move was vital to restore the public image and to continue gaining trust from the investors who did not carefully study and comprehend their dwindling financial situation (Shaban et al., 2017). Although the transactions were typically liabilities, they were recorded in terms of sales and this rescued the public image of the company. Towards the first quarters of 2008, Lehman Brothers did not publicly display the liabilities gained from the repo 105 transactions. They secured loans and used them to settle other debts in the bid to rescue the financial condition that was steadily going down. The repo 105, thus, aided to reduce its liabilities in the balance sheets as sales. The transactions, therefore, consisted of two major processes. The first was to secure the repo 105 loans from other companies without any records and secondly to record the credits as sales, thus reducing the existing picture of liabilities (Dosdall \& Rom-Jensen, 2017). To the public, it appeared the firm was gaining momentum amid the storm that affected the United States' stock market, especially the mortgage leveraging firms.

The method yielded great success for the financial team of Lehman brothers by the ability to reduce their balance sheet liabilities in the last quarter of 2007, the first quarter of 2008 and the second quarter of 2008. The liabilities were reduced by 36.8 billion USD, 49.1 billion USD and 50.38 billion USD, respectively. The global financial controller noticed the use of the repo 105 transactions without disclosure to the public and warned of a reputational risk that existed if the company would not enhance transparency to the public on how the liabilities were reducing significantly. Different financial analysts also sought 
to understand, but the company did not come clear. Lehman's directors, government regulators and the rating agencies failed to realize the use of repo105 transactions to reduce the balance sheets at the end of every quarter (Dosdall \& Rom-Jensen, 2017). The accounting rules, however, permitted the practice of treating repo 105 transactions as sales. The only problem would be the transparency issues that were not shared with the public, and this would risk the reputation of the company.

\subsection{Repo 105 Transactions and the Legal Aspects}

The repo 105 transactions were two-way transactions that were treated complete after the borrower paid back the loans to receive back their collaterals. It was, therefore, not an obligation for the auditors to record transactions by them being incomplete and by the fact that the company treated them as sales. The incoming cash were, however, used to settle the existing liabilities; thus, the firm made consistent progress. There are two significant properties of the transactions which helped the Lehman Brothers during the period of malpractice. These are:

- The first characteristic was that the securities were transferred to other companies without them being omitted from the balance sheets (Dosdall \& Rom-Jensen, 2017). This ensured that the imbalance created by leveraging the securities as collaterals was not captured.

- The other property of the transaction was that the incoming cash was recorded as sales, which was an asset to the company. This helped the firm to reduce the liabilities on paper but not in reality.

The practice was filled with many unethical practices in financial investment. In the long run, it dearly cost the company. The malpractices could, however, have been avoided if every sector of the firm's management engaged professionally to curb the mess that Lehman brothers were pioneering. The senior management team, the risk management team, the external auditors, and other parties all had a significant role in the malpractices through the repo 105 transactions (Wiggins \& Metrick, 2019). It was clear that the intention was to conceal the critical information about the company from the public investors. Figure 2 below gives a flow of the Repo 105 of Lehman Brothers Inc. Europe.

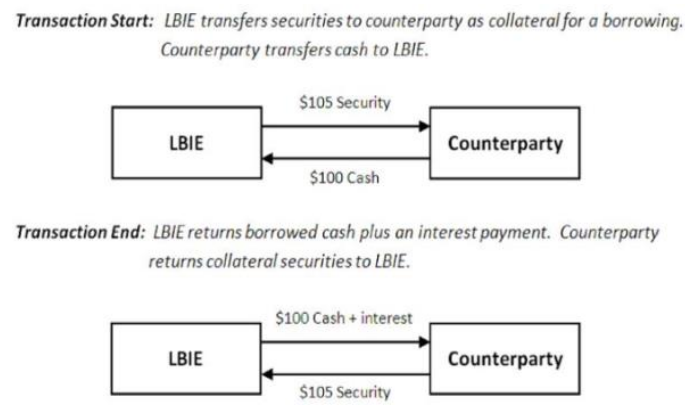

Figure 2 Repo 105 Flow Diagram, Source: Wiggins \& Metrick, 2019

\subsection{Repo 105 and Role of the Senior Managers}

The senior management team, which comprises of all the executive managers were responsible for the sudden collapse of Lehman Brothers. The management team of a financial investment company should be the most active evaluators of the company's financial statements and overall progress. Unfortunately, too much happened without professional control of the situation that took place in the firm. The managers failed in several ways to protect the company from the imminent failure, which they could forecast based on their modes of operations. They engaged in ethical malpractices, which killed the dreams of the company. They failed to uphold four primary standards of professional, ethical conducts and all these are the core reasons why the company failed to materialize in the long run. They include:

- Professional conduct

- The duty to clients

- The duty to employers and

- The integrity of the capital markets.

The central concept of ethics in investments is the ability to cultivate honesty and integrity in every business activity that is carried out.

Professional Misconduct: Ethical codes of conduct demand different aspects of professionalism, which include the knowledge and practice of the law in a way that does not risk the interests of the clients, and the objectivity (Maxwell, 2017). The professionals were away from the law, and they engaged in lawful deals through the repo 105 transactions. The intentions were, however, far from exhibiting professionalism. They did not satisfy the concept of protecting the interest of the clients in the business. They all looked into ways in which they would encourage more investment even with the financial condition, which was growing worse on most occasions. They were, therefore, unprofessional in their practice to use accounting laws to their benefit and to risk the interests of the investors. The other aspect of professionalism that lacked was the failure to maintain the objectives of the company. The management team should always focus on vital interests. The CEO and the chairman position were all owned by one person, Mr. Richard Fuld (Beccar-Varela et al., 2017). He controlled the ownership of the company with more than 50\% control (Beccar-Varela et al., 2017). The other managers had little input in decision- 
making and were not regularly consulted. This was detrimental because it led to the formalization and the engagement in the repo 105 transactions without comprehensive executive approval. It was also against the interests and objectives of the company. Furthermore, it was against the core value of sustainability, which was a principle of operation of the Lehman Brothers group. Lack of professionalism was the first indication or breach of the moral philosophy in investment that contributed to the great fall of the Lehman Brothers.

Duty to Clients: This is sub-divided into three parts. These are

- Loyalty,

- Fair dealing and

- Suitability.

Loyalty: The primary value of ethics is usually to enhance customer service satisfactorily. However, it was the most compromised consideration by the senior management team. On their duties to their clients, they disregarded loyalty, fair dealing and suitability. All these aspects placed the investments of the clients at risk. On loyalty, they failed to uphold integrity and honesty. In the quarterly reports, the off-balance sheet transactions were mainly meant to deceive the public investors of the strong financial position in the stock market (Crosinaand Pratt, 2019).

However, the company was registering significant losses and depreciation in their asset values. The ethical concept of loyalty dictates that the company should act to demonstrate care and concern for the investors' interests by making wise decisions on how to go about their financial assets. The decision to use the repo 105 transactions, which began in the year 2001, was able to conceal the downward trend by reporting a reduction in the liabilities for long (Burks et al., 2018). This continued to lure the clients to the investment company, yet it was a false financial statistic. The concept of loyalty revolves around transparency. It is essential to disclose critical financial information about the company to the investors to help them decide wisely on the number of equities to purchase. The senior leaders were, instead, filled with the desire to fulfil their gains and did not care to involve the investors and other stakeholders in the decisions they made. This was also unfair and unethical. It misled new investors to purchase more equities and it gave false hopes to their shareholders.

Fair Dealing: The other way in which it failed to exercise the duty to their clients was by not practicing fair dealing. It is always crucial that the interests of the clients are factored in the plan of the company. The concept of fair dealing entails that an investment company should ensure that it enters a fair deal with the clients by providing investment analysis and listening to their recommendations. The senior management headed by the CEO and the chairman did not consult broadly. They also failed to listen to various suggestions from experts who gave their opinions. In this manner, they were unable to uphold the ethical value of fair dealing by listening to the recommendations of every stakeholder after providing detailed investment analysis. Furthermore, the company did not produce the correct investment analysis, an act that was legally covered through the use of the repo 105 transactions.

Suitability: The last ethical duty to the clients that the senior management team failed to uphold was the aspect of suitability. The considerations of ethics demand that the firm should ensure that they assess, evaluate and pick suitable investments for the clients. Lehman Brothers, being a renowned company that had flourished in the financial market over the years, should have assessed the condition through the financial forecasting techniques and invested in a less volatile sector. The leveraging was constant even though the housing sector continued to show significant depreciation by the clients failing to honour the payment of mortgages duly. The decision to focus on mortgage leverages, especially from the year 2001, was against the ethical practice of suitability. A careful study of the investment market would have prevented the firm from acquiring five investment companies and continuing to carry out leverages without the considerations of the life-time and the profitability of the business. This placed the customer's investment at risk. The chief financial officer, in collaboration with the CEO, was responsible for such actions that ended up collapsing the firm.

Duty to Employers: The primary responsibility to the employers, which was adversely missing, was still the concept of ethical loyalty. The professional standard code of ethics for the investment companies calls for honest dedication and allegiance to the service of the company's owners (Adu-Gyamfi, 2016). This was affected by the fact that Mr. Fuld was the $\mathrm{CEO}$ in the executive management and the chairman of the board at the same time. While (according to the company's regulatory standards), the board was the overall decision-making organ, its independence was primarily affected by the direct control from the executive organ. This was largely made possible because the chairman of the board was also the head of the executive committee. Technically, the loyalty to the employers was evident because the executive members helped in concealing the repo 105 transactions and carried out their duties according to the instructions issued by the chairman.

However, theoretically, Mr. Richard Fuld failed to recognize that the board was the overall decision-making organ and was supposed to be consulted before making significant decisions. Although he was the chairman of the same board, he was not legible to make board decisions alone. This was detrimental because the lack of consultatory efforts from other members led to the loss of loyalty. The executive team and the board members did not work in harmony to prevent the irregularities that were happening in the company (Adu-Gyamfi, 2016). This is a lesson to organizations that it is vital to have an independent decision-making organ outside the executive committee. The chairman of the board is more effective if he does not work on 
the board as well. This would have prevented the misuse of power by Mr. Richard Fuld and his lack of responsibility to report to the board some of the critical decisions that were being made in the company.

\section{The Integrity of the Capital Market}

As earlier stated, the main idea behind the philosophy of ethics in investment is to enhance integrity in the capital market. Integrity was the main issue that led to all other ethical proceedings (Burks et al., 2018). In the capital market, it is not right to either possess non-public information that influences the value of an investment or to engage in any practice that manipulates the capital market. Failure to observe these is considered unethical and may lead to the loss of investors' confidence in the financial firm. Unfortunately, these were the main parallels behind the repo 105 reports. The senior management team acted legally in every manner but failed to consider ethics in their actions. Ethics, according to the deontological theoretical framework, is a natural law that should spring out naturally. It was unable to show up among the senior managers led by Richard Fuld; hence the company failed terribly in the following two aspects. These are:

- Non-Public Information

- Market manipulation

Importance of Non-Public Information: Ethics demand that members in possession of information, which is not in the public domain, should not endeavour to act in a manner that influences the value of investments or cause others to act on the information (Maxwell, 2017). Although the senior managers may not have disclosed the high-profile internal secrets to the members of the public, they acted to influence the capital market using their information. They continued to leverage mortgages as they used the repo 105 transactions to reduce liabilities. In reality, the securities were being transferred to the lender companies gradually, and this would eventually lead to a significant loss if the mess were not corrected in good time. The consideration of this standard of ethics in their practice was, therefore, not upheld to the maximal required standard.

Market Manipulation: The senior managers were the primary market manipulators. The standard of codes for ethics in investment companies also cautions against the behaviour of manipulating the market for individual gains. The use of repo 105 as off-balance sheet transactions was mainly for the manipulation of the capital market (Schiereck et al., 2016).

The information was neither availed in the regular reporting of balance sheets nor were the rating urgencies and the government regulators informed of the proceedings that were taking place. The engagement was, thus, regarded as a topsecret among the senior officials in the companies. The failure of the rating urgencies and the government stock market regulators to be adequately informed of whatever taking place was to continue to evade the poor publicity in the capital market, which would influence the number of people who bought their equities. The continuous addition of assets in the form of sales from the repo 105 transactions and failure to credit the liabilities gave a constant reduction in the value of debts and a consistent rise in the value of the assets.

In the end, the indication was positive all the years from the year 2001, and this indicated a tremendous improvement (Beccar-Varela et al., 2017). Many investors continued to vest their capital upon the faith of the unprofessional managers unknowingly. Consequently, the practice to conceal critical information from the public was very inconsiderate and unethical by the senior management team of the company. Their unethical behaviour played a significant role in the collapse of the company.

\subsection{Repo 105 and Role of the Risk Management Department}

The risk management team is a critical area in an investment company. Failure to adequately plan for the risks that may occur during various transactional operations may lead to significant losses. The risk management team can blame its shortcomings to the executive group because of the great control they had in the company during the considerable period of economic depression that eventually led to their collapse (Maxwell, 2017). As stated, prior, the CEO had extensive control and may have probably affected the efforts of the risk management team. However, it is difficult for such a department to escape the full blame as long as they were in operation.

The risk management department has the task of upholding three dominant ethical values, which include failure to exercise diligence in market analysis and communication with clients (Fitzpatrick \& Thomson, 2016). Regarding diligence, the risk management team needs to understand the movement of the assets and liabilities in the company. They were responsible for continuous feasibility study and determining the right investments that Lehman Brothers should have laid more efforts. However, the risk management team did not work hard to realize that the mortgage leveraging was volatile and would cost Lehman Brothers in the long run. The chief risk management officer, who was also the vice president Mr. Madelyn Antoncic acknowledges that the wounds were self-generated by the failure to act with transparency and honesty (Beduneau and Gizard, 2016).

He also acknowledges that lack of proper analysis and forecasting led to the continuous leveraging of mortgage firms, leading to the collapse. The attempt to cover for the liabilities to gain more equities from the public also turned out more unethical, and it cost the firm reputation. The risk management team also failed to communicate with the clients on the financial risks during that time. They did not continually advise on the best ways to carry on with the practice of investment. Instead, they continued to hide behind the repo 105 without raising the alarm to the clients on the impending danger and the false balance sheet information that was being presented through the transactions. 


\subsection{Repo 105 and Role of External Auditors}

External auditors would have been the saviours of the company from the gross malpractice. However, they also seem to have been included in the mess by failing to detect the constant malpractices in the accounting malpractices of the company. They engaged in unprofessional acts to conceal the manipulations in the balance sheets to cover for the senior managers who were the pioneers of the whole story (McKinley, 2017). Ernest and Young have since then faced a legal struggle in the New York corridors of justice to explain the occurrences and how they failed to notice the inconsistencies in the transactions every quarter. The firm, however, was tasked with the primary duty of affirming whether accounting rules are applied in all the transactions.

The use of repo 105 was not illegal. It was unethical to use it and fail to disclose the transfer of securities to other parties. However, since the repo 105 transactions were only considered complete after the repurchase of the securities, they could not be included in the legal statements (Schiereck et. al., 2016). The auditing firms should, however, communicate every inconsistency to the public. Ernest and Young failed to exercise the duty to the clients by not being loyal and truthful. They also failed to integrity to the capital markets by not reporting the errors in the balance sheets of Lehman Brothers. The other employees of the company had an insignificant impact because the CEO, Mr. Richard Fuld, strictly managed the decisionmaking of the company.

\section{Conclusion}

Ethics is a branch of moral philosophy that naturally enables one to perform what is right. The theoretical concept of ethics in investment played a vital role in the financial depression that occurred in the United States in the year 2008. Lehman Brothers were among the best investment firms in the USA during that time. They ranked fourth in the national statistics. However, they engaged in many issues without transparency and sustainability. Such is against behavioural ethics in investment firms. Ethical malpractices were core in the fall of the Lehman Brothers' investment company.

The firm invested without a proper analysis as required by ethics. Failure to conduct useful marketing research led to excess leveraging of mortgage firms. They acquired five leading mortgage firms and engaged in both subprime and prime leveraging. The housing leveraging and the real estate business in the United States, however, registered significant losses in the years 2007 and 2008. These sharply reduced the profit-making ration of the company. It had an investment in the use of repo 105 transactions in the year 2001. During the whole period, it was able to conceal a considerable amount of liabilities through the repo 105 transactions.

Repo 105 deals were recorded as sales making the firm gain assets in the balance sheets. However, they did not adequately document the transfer of securities. The practice helped them to cover for the losses even during the late stages of its collapse as the great financial depression of 2008 hit the USA. The senior management team is more responsible than other stakeholders because of their inability to exercise ethical duties to employers, investors, the capital market, and the lack of professional display. The external auditors also contributed to the malpractice by failing to notify the regulating authorities of the alterations in the accounting statements. Lastly, the risk management team was unable to carry out a practical risk analysis to prevent the problem from affecting the company in such a magnitude. Ethics are; thus, necessary in the practice of investment banking.

\subsection{Future Aspects}

The study displays the significance of ethics in investment banking. The case of the Lehman Brothers investment firm points out some of the other weaker areas of the field that would need more research. The first area is the management culture. The senior executive management primarily contributed to the failure to uphold the dignity of the company. It is, therefore, essential to understanding the role of executive management in implementing ethical regulations. It is also necessary to improve the independence of the external bodies in various investment firms. Such include the board of directors and the external auditors. They were both acting under the control of the executive. The committee did not work as a significant decision-making organ, and this contributed to them not being aware of using repo 105 transactions to mislead the public and other financial institutions. It is, therefore, important for investment companies to give the external parties ample time to carry out their responsibilities without compromising the quality of operations.

The use of the repo 105 transactions should also be reviewed legally to cater for the ethical needs in investment banking. Such transactions should not be treated as sales. They should be accredited as more liabilities because they include more deductions. All those studies will labour on building a firm ground for the already existing theoretical knowledge on the practice of ethical philosophy concerning investment banking. The broad future research in management and the repo 105 reports will open room for more dialogue on the matter of ethics in financial institutions and governance. It will set a clear standard between those who honour ethics and those who do not. Success is usually dependent on the level of discipline and professionalism exhibited by an individual.

\section{References}

1. Adu-Gyamfi, M., (2016), 'The bankruptcy of Lehman Brothers: Causes, effects and lessons learnt', Journal of Insurance and Financial Management, Vol. 1(4).

2. Beccar-Varela, M. P., Mariani, M. C., Tweneboah, O. K., Florescu, I., (2017), 'Analysis of the Lehman Brothers collapse and the Flash Crash event by applying wavelets methodologies', Physica A: Statistical Mechanics and its Applications, 
Vol. 474, 162-171.

3. Beduneau, G., Gizard, B., (2016), 'Ethical Issues in Finance', Finance and Economy for Society: Integrating Sustainability, 125-137.

4. Bhala, K. T., Yeh, W., Bhala, R., (2016), 'International Investment Management: Theory, Ethics and Practice', Routledge.

5. Booth, P., (2010), 'The Crash of 2008-the Relationship with Ethical Issues', Finance Bien Commun, Vol. 1, $39-53$.

6. Bruce, I., (2018), 'What We Still Have to Learn from the Credit Collapse (and Other Market Crises)', 'The Journal of Portfolio Management, Vol. 45 (1).

7. Burks, N., Li, B., Bowling, J., Schmid, N., (2018), 'capitalizing off collapse: The hidden alpha during the crisis periods', International Research Journal of Applied Finance, Vol. 9(3), 124-133.

8. Care, R., (2018), 'Ethics and finance: The unresolved puzzle', In: Sustainable Banking, 11-37, Palgrave Pivot, Cham.

9. Crosina, E., Pratt, M. G., (2019), 'Toward a model of organizational mourning: The case of former Lehman Brothers bankers, Academy of Management Journal, Vol. 62(1), 66-98.

10. De Roeck, K., Farooq, O., (2018), 'Corporate social responsibility and ethical leadership: Investigating their interactive effect on employees' socially responsible behaviors', Journal of Business Ethics, Vol. 151(4), 923-939.

11. Dosdall, H., Rom-Jensen, B. Z., (2017), 'Letting Lehman go: Critique, social change, and the demise of Lehman Brothers', Historical Social Research/HistorischeSozialforschung, 196-217.

12. Fitzpatrick, T. J., Thomson, J. B., (2016), 'Lehman Brothers bankruptcy, what lessons can be drawn?', In: Banking Crises, 213-220, Palgrave Macmillan, London.

13. Maxwell, B., (2017), 'Codes of professional conduct and ethics education for future teachers', Philosophical Inquiry in Education, Vol. 24(4), 323-347.

14. McKinley, V., (2017), 'Is there value in revisiting the Lehman collapse?', Regulation, Vol. 40, 48.

15. Mieszala, R., (2019), 'Impact of the collapse of the Lehman Brothers bank and the 2008 financial crisis on global economic security', Scientific Journal of the Military University of Land Forces, Vol. 51.

16. Reynolds, J. N., Newell, E., (2011), 'Ethics in Investment Banking', Springer.

17. Schiereck, D., Kiesel, F., Kolaric, S., (2016), 'Brexit :( Not) another Lehman moment for banks?' Finance Research Letters, Vol. 19, 291-297.

18. Shaban, O. S., Abdallah, A. A., Al-Ibbini, O. A., (2017), 'Financial Crisis between Personnel Misbehavior, Corporate Governance and Absence of Ethics and Values', International Research Journal of Applied Finance, Vol. 8(5), $264-272$.

19. Valukas, A., Bradford, D. J., Murray, D. R., McArn, H. D. (2010), 'United States Bankruptcy Court Southern District New York', Lehman Brothers Inc,

20. Wiggins, R. Z., Metrick, A., (2019), 'The Lehman Brothers bankruptcy B: Risk limits and stress tests', Journal of Financial Crises, Vol. 1(1), 3. 